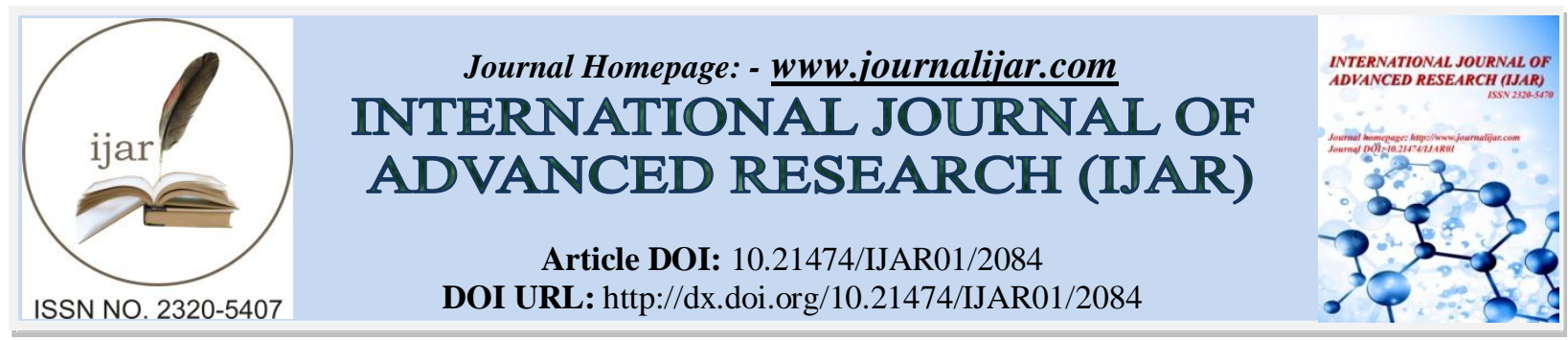

RESEARCH ARTICLE

\title{
ENGAGED EMPLOYEES IN INSTITUTES OF HIGHER EDUCATION.
}

"S.T. Janetius ${ }^{1}$, R. Padmanabhan ${ }^{2}$ and Mini TC'

1. Director, Centre for Counselling \& Guidance, Sree Saraswathi Thyagaraja College, Pollachi - 642107 .

2. Dean Academic Affairs, Sree Saraswathi Thyagaraja College, Pollachi, Tamil Nadu.

3. Principal, SMS College of Arts \& Science, Coimbatore, Tamil Nadu.

\section{Manuscript Info}

Manuscript History

Received: 24 September 2016

Final Accepted: 26 October 2016

Published: November 2016

Key words:-

engaged employee, employee in higher education, employee disengagement, corporate vs. educational culture

\begin{abstract}
Employee engagement has become a popular theme amongst Industrial and Organizational Psychologists today due to the global dictum 'perform or perish' and the strong competition for projected profits and continued existence among organizations. Employee engagement is a broadly studied concept in the corporate sector and defined elaborately by various authors. Generally, it is defined as the emotional attachment and commitment an employee has towards his/her job, colleagues, and organization that profoundly influence the level of performance, commitment, and loyalty. Since the defining concept and parameters used to explain employee engagement purely originate in the industrial sector, the researchers of this study speculate whether or not this concept could be applicable in the educational sector too. Further, the study also answers the following questions. i) What are the characteristics of engaged employee in institutes of higher education? ii) What are the antecedents of engaged employee in IHE? and iii) What are the managerial factors contribute to employee engagement and disengagement in IHE?
\end{abstract}

Copy Right, IJAR, 2016,. All rights reserved.

\section{Introduction:-}

Global competitiveness among organizations has made employee engagement a hot topic of discussion in the recent years. Engaged employee or employee engagement is a widely used and explored area in the corporate world while in the educational sector, it has been hardly studied (Robinson et al., 2004). Although many studies point out a strong correlation between employee engagement and individual and team performance, desirable business outcomes, less attrition, better customer care, business growth and productivity, organizational success, and financial performance (Bates, 2004; Harter et al., 2002) there is no one single definition of employee engagement. Many a times, it is defined in relation to the organizational commitment and organizational behaviour like emotional and intellectual commitment to the organization (Shaw, 2005). Saks (2006) defines employee engagement as the distinct and unique construct that consists of cognitive, emotional, and behavioural components that are associated with an individual's role performance. According to Kahn (1990), employee engagement is closely associated with personal engagement that is the psychological presence in performing an organizational role, in which a person involves physically, cognitively, and emotionally. While defining employee engagement as the attention an employee gives and the amount of time one spends thinking about the role, Rothbard (2001) differentiates two types of employee engagement viz. job and organization engagements. Organisation engagement is understood as the degree to which an employee identifies with the goals and values of the organization, and is willing to put in efforts

Corresponding Author:- S.T. Janetius.

Address:- Director, Centre for Counselling \& Guidance, Sree Saraswathi Thyagaraja College, Pollachi - 
to help the organization to achieve these goals (Herscovitch and Meyer, 2002). Muthuveloo and Rose (2005) also see organizational engagement as the willingness of employees to accept the goals and values of the organization and to work towards the achievement of these goals. Bux (2011) who made a study on job engagement and organization engagement identifies job-engaged employees to display a higher level of dedication while organization engaged employees display higher job satisfaction. Employee engagement is different from job involvement. Many people misinterpret commitment as engagement. Organizational commitment is an attitude of an employee but engagement is the amount of individual's attentive absorption in the performance of the job (Saks, 2006).

The three psychological factors 'meaningfulness, safety and availability' proposed by Kahn (1990) was empirically tested by May et al (2004) and found that they were significantly related to engagement. They further identified, job enrichment and role fit were positive predictors of psychological meaningfulness; rewarding co-worker and supportive supervisor relations were positive predictors of psychological safety and resources available were a positive predictor of psychological availability. Maslach et al. (2001) understand job engagement as the positive antithesis of burnout remarking that burnout involves the corrosion of engagement with one's job, pointing out the following six areas of work-life workload, control, rewards and recognition, community and social support, perceived fairness, and values as the key to engagement. Saks (2006) who tried to identify a theoretical foundation to explain engaged employee, links the widespread Social Exchange Theory with Kahn (1990) and Maslach et al (2001). He explains that the amount of cognitive, emotional, and physical resources that an individual prepares to devote in the performance of one's work roles is contingent on the economic and socio-emotional resources received from the organization. He further reiterates Social Exchange Theory with employee engagement saying that the employees choose to engage themselves to vary degrees in response to the resources they receive from their organization. Research findings also identify relationships between engagement and intention to quit, job performance and extra-role behaviour (Schaufeli\& Bakker, 2004; Sonnentag, 2003).

\section{Objectives of the study:-}

Educational institutions all over the world compete like corporate enterprises and this change affects the overall nature and outlook of teachers. Since the defining concept and parameters used to explain employee engagement solely originate from the industrial sector, this research focuses on defining the concept in the educational sector. In view of defining engaged employee in an education institution, this study answers the following questions: i) what are the characteristics of engaged employee in Institutes of Higher Education? ii) what are the antecedents of engaged employee in IHE? and, iii) what are the managerial factors contribute to employee engagement and disengagement in IHE?

\section{Methodology:-}

This three-phased qualitative descriptive exploratory study was started in the month of September-October 2013. A total number of 265 college teachers from eight colleges in the Coimbatore region in Tamil Nadu participated in the study. In the first phase, a survey was taken which focused on the characteristics of engaged employee, the antecedents and other contributing factors both personal and managerial. Using a theoretical editing analysis protocol, themes and categories were formed to develop conceptual themes (Strauss \& Corbin, 1990). In the second phase, a sixteen-item Likert scale measured the employee engagement. The questions focused on four identified factors in the first phase. Teachers were asked to mark their responses on a Likert scale with anchors (1) strongly disagree to (5) strongly agree. The items were consistent as per factor analysis and all items were 0.76 or higher. In the third phase, seven selected teachers who were identified as engaged employee by other faculty members were interviewed further for qualitative discussion. Provisional themes and categories derived from the survey were reexamined and discussed with these scholars and conceptual themes were developed.

\section{Results and Discussion:-}

The average age of the participants was 41 ; the male-female ratio was $8: 17$. The participants were in the teaching profession for an average of 6-8 years and, in their current job for an average of three years. The majority of the participants $(97 \%)$ work in self-financing institutions and 3\% work in Government colleges. Nearly half of the teacher work (45\%) in Arts and Science Colleges and 31\% teach professional courses, $21 \%$ in engineering colleges. 
Table 1:- showing background information of subjects

\begin{tabular}{|l|l|l|l|l|l|l|l|l|l|l|}
\hline Age & & & & & & Gender & \multicolumn{2}{l|}{ Place of Work } \\
\hline$<30$ & $31-40$ & $41-50$ & $51-60$ & $>60$ & M & F & $\begin{array}{l}\text { Govt. } \\
\text { Arts \& } \\
\text { Science }\end{array}$ & $\begin{array}{l}\text { Self- } \\
\begin{array}{l}\text { Finance } \\
\text { Arts \& } \\
\text { Science }\end{array}\end{array}$ & $\begin{array}{l}\text { Self- } \\
\text { Finance } \\
\text { MBA \& } \\
\text { MCA }\end{array}$ & $\begin{array}{l}\text { Self- } \\
\text { Finance } \\
\text { Eng. }\end{array}$ \\
\hline 20.4 & 30.2 & 24.5 & 20 & 4.9 & 32 & 68 & 3 & 45 & 31 & 21 \\
\hline
\end{tabular}

The study results identified the following five factors as antecedents and attributes of an engaged employee in educational institutions. They are: 1) emotional maturity, 2) personal integrity, 3) resourcefulness, 4) feeling proud of the profession and, 5) altruism. The engaged employee is an integrated personality of sober temperaments with personal values and emotional maturity, good in subject knowledge, technical ability and resourcefulness, loyal to the students and committed to their welfare. Consequently, the study defines engaged employee as 'one who is highly resourceful, driven by a pious and holy objective of helping and assisting students in terms of imparting knowledge, development of skills, providing values and thus committed to their overall welfare'. The significant characteristics of an engaged employee identified are i) psychological presence, ii) emotional involvement, iii) time and energy voluntarily spent in executing duty, iv) intentionally involved in student development activities.

The study results quantify 28 percent of the surveyed teachers as engaged employees. Of this, 62 percent have personal satisfaction; 26 percent have job satisfaction and 12 percent feel both personal as well as job satisfaction. Results also indicate that there is a significant difference between personal and job satisfaction as well as job and organization engagement. Personal satisfaction is understood to arise from the commitment and dedication the person has towards the students and the passion for teaching whereas job satisfaction is understood in terms of the organization as well. Nearly 78 percent of the participants expressed job engagement as the basic trait of an engaged employee in educational institutions and 14 percent organizational engagement. Only eight percent expressed that both job engagement and organizational engagement are needed to label engaged employee.

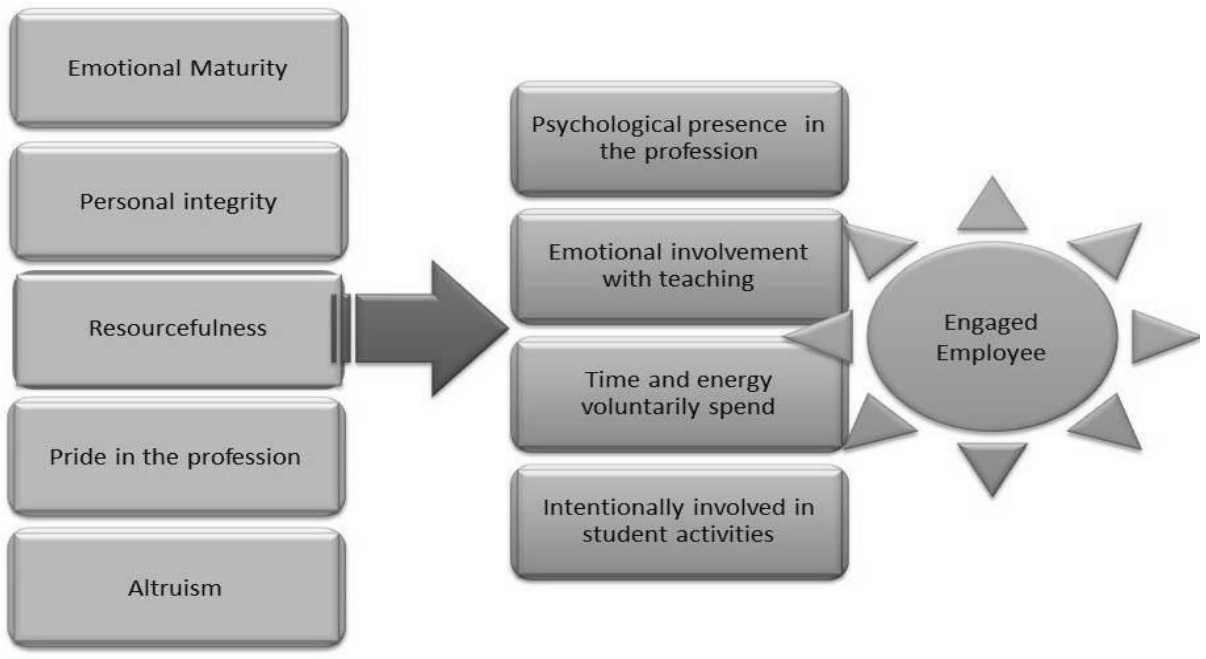

Figure 1: showing antecedents and characteristics of engaged employee in educational institution

As regards the corporate culture, emotional attachment and commitment an employee has towards his/her organization is essential since the goal and motto of any business organization is benefits; whereas education institutions, in the truest sense, are supposedly non-profit organizations, solely running for the welfare of students. Loyalty to the management or organization sometimes becomes a hindrance to many teachers to dedicate themselves fully in the welfare of the students, when they see that the management is hostile towards students as well as employees. Since 97 percent of the subjects being studied work in self-financing colleges, a clear distinction between organizational commitment and job commitment has been reflected in the study results. Loyalty to the institution sometimes becomes a hindrance to commit them for student's welfare. Many subjects of the study expressed concerns that the personal values and philosophy of life goes against the organizational culture. The hostile and unfriendly management and the various practices focused on monetary benefits become a hindrance to job satisfaction and organizational commitment. 
The study has identified four kinds of teachers: a) committed to the organization and student's welfare, b) committed to the profession focusing on the students and, personal/professional growth, c) work for the sake of job security and salary, d) sluggish and unfocused employee. The first two categories are engaged employees. These committed ones work for the growth of the organization as well as students and, work purely on the student welfare and thus take pleasure in the job done and gain personal/professional growth. The second two categories are non-engaged employees who involve in selected activities for the sake of job security and monetary benefits. These are sluggish, uninvolved and irresponsible personalities and become a burden to the organization. The teaching profession, which is traditionally a service in the Indian context, has become a place of an easy job for many graduates today, thus increases the number of the non-committed, un-engaged employee.

The managerial constraints that cause concern for the engaged employee are: poor compensation/benefits, lack of concern for employees wellbeing, unfriendly and rude dealings, poor HR practices, primary and secondary monetary profit orientation, deprivation of freedom to perform and, poor work-life balance caused by lack of holidays, leisure time and work overloads. The subjects identify the following factors as some of the major hindrance from the part of hostile management for employee engagement:

* No gratitude for any hard work done

* Clear policies and defined roles are not given to employees

* Lack of job security and proper salary benefits

* Non-existent HRM or poor HR practices

* Defined work time does not exist

* Torturous work overloads leading to stress and poor work-life balance

* Employee well-being is never considered - I have invested attitude

* Too much bossism leading to 'I pay you - you work for me, do what I say' attitude

* Non-consultation in major academic decision makings

* Management thinks and acts as self-proclaimed genius

\section{Conclusion:-}

The study concludes that the concept engaged employee in Institutes of Higher Education is significantly different from the corporate sector. Although various research findings in the corporate sector show that the employee's commitment to the organization is a significant factor in defining employee engagement, in the education sector, commitment to the job and student welfare takes precedence. The findings of the study indicate that only a fraction of employees are committed to the student welfare and thus, could be labelled as engaged employee. As increased number of educational institutions that run for commercial purposes with economical profit motives, the noble teaching profession has become an easy job-seeking arena for many young graduates thus reducing the quality of commitment and dedication needed for the profession. Various management practices, especially in the selffinancing colleges, have becomes a hindrance for many to commit and dedicate themselves for the welfare of the students. Further studies could be done to quantify and validate the identified variables.

\section{References:-}

1. Bates, S. (2004). Getting engaged, HR Magazine, Vol. 49 No. 2, pp. 44-51.

2. Bux, S.R. (2011). Whither Job Engagement or Organization Engagement for Job Satisfied and Dedicated employees? International Journal of Contemporary Business Studies, Vol: 2, No: 11. November, 2011 ISSN 2156-7506.

3. Harter, J.K., Schmidt, F.L. and Hayes, T.L. (2002). Business-unit level relationship between employee satisfaction, employee engagement, and business outcomes: a meta-analysis, Journal of Applied Psychology, Vol. 87, pp. 268-79.

4. Herscovitch, L. \& Meyer, J. P. (2002). Commitment to Organization Change: Extension of three component model. Journal of Applied Psychology, Vol.87 pp 474-487.

5. Kahn, W.A. (1990). Psychological conditions of personal engagement and disengagement at work, Academy of Management Journal, Vol. 33, pp. 692-724.

6. Maslach, C., Schaufelli, W.B. and Leiter, M.P. (2001). Job burnout, Annual Review of Psychology, Vol. 52, pp. 397-422.

7. May, D.R., Gilson, R.L. and Harter, L.M. (2004).The psychological conditions of meaningfulness, safety and availability and the engagement of the human spirit at work, Journal of Occupational \& Organizational Psychology, Vol. 77, pp. 11-37. 
8. Muthuveloo, R. \& Rose, R.C. (2005). Typology of Organisational Commitment. American Journal of Applied Science, 2 (6) 1078-1081.

9. Robinson, D., Perryman, S. \& Hayday, S. (2004). The Drivers of Employee Engagement, Institute for Employment Studies, Brighton.

10. Rothbard, N.P. (2001). Enriching or depleting? The dynamics of engagement in work and family roles, Administrative Science Quarterly, Vol. 46, pp. 655-84.

11. Saks, A. (2006). Antecedents and consequences of employee engagement, Journal of Managerial Psychology, Vol. 21 No. 7, pp. 600-619.

12. Schaufeli, W.B. \& Bakker, A.B. (2004). Job demands, job resources, and their relationship with burnout and engagement: a multi-sample study, Journal of Organizational Behavior, Vol. 25, pp. 293-315.

13. Shaw, K. (2005). An engagement strategy process for communicators, Strategic Communication Management, Vol. 9 No. 3, pp. 26-29.

14. Sonnentag, S. (2003). Recovery, work engagement, and proactive behavior: a new look at the interface between non-work and work, Journal of Applied Psychology, Vol. 88, pp. 518-28. 